\title{
Comparative Analysis of Women's Rights in the United States and Modern China
}

\author{
Jinyu Xie ${ }^{1^{*}}$, Chuanji Zhang ${ }^{2}$ \\ ${ }^{1}$ Meadowridge School, Maple Ridge, British Columbia, Canada \\ ${ }^{2}$ The Hotchkiss School, Lakeville, Connecticut, USA \\ *jinyu.oren.xie@gmail.com
}

\begin{abstract}
In most contemporary media coverage and public impression, the legislation in the United States and certain European countries are perceived to place a high emphasis on human rights and individual liberty. Additionally, the western-style legal systems are universally recognized as the modern form of law for human society. In contrast, the laws of traditional eastern countries such as China are often depicted as corrupted, outdated, irrational, and hierarchical, which contradicts the fundamental principles of humanitarianism. This paper analyzes the legislative history of women's rights in the United States and modern China. Through a close reading of both countries' legal codes produced during the late nineteenth and twentieth centuries, this paper seeks to provide a revisionist understanding of the interactions between the development of legislation, social movements, and individual perception of the law.
\end{abstract}

Keywords: Women rights, legislative history, comparative Analysis, China, United States

\section{COMPARISON}

\subsection{China}

During the political turmoil in the late nineteenth and early twentieth century, women's rights in China had evolved dramatically due to substantial influence brought in by foreign countries that had ultimately led to modernization and reformation of the country. Women's new rights, as legally stated and protected by the newly written Constitution of the Republic, were unarguably a huge step forward to reach gender equality, yet their validity in practice was still questionable. Moreover, as the KuoMinTang regime (1928-1949, the leading political party of the Republic in the early 20th century) attempted to adopt similar legislation of that in contemporary Western countries, some fundamental rights, protected by the previous Qing Dynasty (1644 1912), were, in fact, neglected.

Due to the heavy influences of Confucianism, China has, since the very beginning of its history, had a tradition of classism and sexism in its society. Although the ideology of a stratified society was mostly broken by the end of the Qing Dynasty as Phillip Huang has shown[1], women were still considered the subordinate will if married. This customary patriarchal family style that is prevalent in imperial Chinese societies stresses women's dependency on men legally and conceptually. During the Qing regime (1644-1912), a woman was a more intimate part of her spousal family than that of her natal family: they were required to perform a three-year consolation for a dead spousal family member while only having to lament for a one-year period if one of her natal family members had passed away. Chastity was viewed with significant importance in the Qing era. Remarriages of widows thus were particularly difficult and unaccepted by convention. The natal family members of a widow would have no right to claim the dowry; and, if a dowry was not given to the spousal family prior to the marriage, the family of the husband would be responsible for her remarriage and collect the betrothal gifts. The Qing Legal Code (1644-1910) was much more lenient to cases where the divorce was propounded by men: disparate from the trivial reasons posed by men, the law only provided the bare minimum to protect women in a marriage[2]: that is, only when she was severely beaten (with broken teeth and/or bones), or when her husband had not returned for more than 3 years, did women have the right to call for a divorce in court[3]. As a result, most divorce cases litigated by wives were unsuccessful.

Nevertheless, the patriarchal logic behind the Qing law meant that it would also provide legal protection for women in both familial and social lives. The foremost provisions concern the issues around abduction, 
seduction, prostitution, and trafficking of both underage and adult females of honorable commoner status. The Qing Code stated that the illegality of all the aforementioned activities, though in practice many of these offenses were tolerated depending on the circumstances[4]. For example, despite the Code explicitly banning the selling of wives and daughters from honorable commoners' households, the judges, in most cases, condoned such practices if "the husbands were forced by poverty" to do so. An entire industry of women trafficking was present in the Qing, and as inhumane as it sounds, it perhaps was beneficial to some lower class women as they were often sold to a better-off family. Although slavery - as in the form of the Atlantic slave trade - has never occurred in Chinese history, many scholars had compared it to concubines and female indentured labor in feudal China. They were unarguably similar in a way as people were all seen as commodities when they were transacted. However, the treatment of these people varied dramatically: enslaved African Americans did no more than harsh drudgery while these concubines and servant girls might have enjoyed a better life than before. The simple rationale is that, besides their social status, no significant difference of any kind could be drawn between the master and the one sold in China, and therefore discrimination such as racism simply did not apply; whereas slave owners, based on the difference in skin color, conjectured that an inherent distinction existed, and a sense of superiority thus arose. As a result, these concubines resembled more indentured servants than slaves. Nevertheless, the distinction between female for sale (illegal) and marriage contracts (legal) was fairly ambiguous as both involved monetary transactions. Perhaps the only difference that sets them apart is the fact that female trafficking only involves one-way cash flow, whereas both families entering a marriage would receive fiscal benefits from each other that are mutually balanced out.

Notwithstanding the unbalanced rights classified on the basis of genders, the Qing government did acknowledge women as active agents that were able to make choices and give consent. For instance, the trafficking of women in traditional China was often facilitated by family members rather than by professional traffickers alone. Therefore, in the selling of one's wife or daughter, the woman's will would be taken into consideration. Instances in which the woman was sold against her will were rarely found in judicial records[5]. Revealed in the numerous articles using the term 'he', women, for most crimes, were too punished even if they were victimized as the government believed that they had an opportunity to decide whether to conform with the criminal allegation.

It is also important to note that during the Qing period, women themselves had a considerable amount of freedom regarding their reproductive rights: that is, abortion per se was never criminalized. Indeed, abortion prior to the Republican era was more of a moral debate than a legal issue. The very term "abortion" was not mentioned in the Qing Legal Code except for instances where abortion was induced by a physical attack, in which the law penalized the assailant barely harsher than that of an assault. It is therefore plausible to deduce that the lawmakers of the Qing dynasty had their primary concern focused on protecting the mother instead of the unborn fetus in cases of miscarriage. Indeed, Confucianism played an important role in the lawmaking process around abortion. Although it emphasized procreation as a critical filial duty that one has to perform, the fundamental principle of this philosophy accentuates a stratified society in which every member was obliged to perform their role without trespassing the social barrier. In a filial relationship in cases like abortion, the parents, especially the husband, had an important say pertaining to the child's life and liberty. As a result, abortion and even infanticide, were accepted practices by the general public. Meanwhile, the interpretation of the difference between a fetus and a fully developed human being had long been debated throughout Chinese history. During the Song dynasty $(960-1279)$, the formation of the human shape was considered as the turning point. However, the conventional approach to this issue was to view the unborn baby as an organ of the mother, but not as individual life. In contrast to western societies, this interpretation was never censured by the public. These ethical arguments render insight into the reasons behind the Qing's attitude towards abortion. Therefore, it is possible to conclude that the Qing government lacked the notion of human rights.

As the nation progressed into the Republican era (1912-1949) in the 1910s, a series of legal codes were drafted based on Western legal traditions in which women were seen as autonomous agents in marriage. Indeed, as foreign imperialist nations asked for extraterritoriality that infringed the legal sovereignty of China, the leading officials inadvertently conceded to revise their laws based on the criteria defined by Western notions such as humanitarianism, liberty, and conjugal equality. No-fault divorce had been legalized since 1930 and women earned their property rights[6]. The foremost change, however, that took place under the Republican era was the advancement of women's political participation and legal consciousness. The so-called bicameral National Assembly of the Beiyang government (1912-1928) provided women a chance to take part in politics for the first time in Chinese history. Although men were still overwhelmingly preponderant in the government, women did have some say in national issues by holding offices in the government and executing suffrage rights for the selected few.

However, this did not come easily. As women were for the first time to receive proper education during the late Qing period, many sought to expand their rights. There were in total three major waves of women's 
suffrage movement dating from the late Qing period all the way to the start of the People's Republic of China $(1949$ - $)$, each led by wealthy, well-educated female leaders who were also active participants of other political movements in this period[7]. As public education prevailed, women had learned to use the law as a weapon in defense of their rights. For example, a marriage case where a woman was forced to marry a man determined by the spousal parents yet she disliked. The case was ruled illegal by the court as the plaintiff put the case into litigation. Debates pertaining to the Constitution were emblazoned across the headlines of local newspapers, thus enabling those of pariah status of the society to discuss and understand their rights.

Although women had gained a considerable amount of equality under the new Constitution, they have become, legally, "a passive agent devoid of will or choice". Nevertheless, abortion had been illegalized in 1910[8] as the legal codes were reformed based on that of Japan and Germany, which took the heavy influence of the Christian ideology: that everyone was created to be equal in front of God, and no one's life should be taken away inadvertently. Considering abortion as an indicator of women's choice on their body, the illegalization marked a significant regression in terms of women's rights in Chinese history. With that being said, though, the court's adjudication on cases involving non-coerced miscarriage was fairly ambiguous. In practice, judges tend to be more lenient as traditional Chinese philosophy does not oppose such behavior. In other words, the judicial reform regarding abortion was done passively as a result of an unprecedented modernization process where foreign elements were forcibly taken in without a consideration of the country's own convention. Indeed, later changes of the law dedicated to adjust to the country's very own circumstance. In 1934, abortion was re-legalized if the mother's health is jeopardized by the pregnancy[9]. This puts an effort to protect the mother instead of the baby once again.

The first decade of the PRC was another period of legal dramatic progression in China. In 1950, only one year after the establishment of the People's Republic, the government promulgated a law broadly protecting the rights of women. The law stressed to break all conventional views of women in marriages and thrives to create gender equality[10]. It was also at this point when abortion was legalized not necessarily as a concern of women rights, but as a means of population control. This was well before the "One Child Policy" that had lasted for decades, and different from the traditional conception of the hackneyed, superannuated Chinese legal system, this code was much more advanced in ideology than that of other countries' in the fifties regarding the issue of gender equality. Perhaps it was even too advanced compared to its contemporaries that the Chinese government abated the Marriage Law of 1950 and reintroduced a regressive set of code in 1980 .

\subsection{United States}

Women went through a sinuous journey to establish their deserved rights in the United States. However, this path was dramatically different from the ones walked by the Chinese women. The factors behind this disparity in the developmental process of women's rights can be attributed to a variety of sources. Some consider this to be caused by the different political ideologies while some claim that the fundamental cultural tradition differences between the west and the east play a larger role. Regardless of the reasons, women of diverse origins in the United States strived for the establishment of their rights both politically amended into the constitution and socially applied to societal views and practices.

The role of women in the colonial era remained similar to those of the women back in Europe. Lacking the right to vote, to serve on juries, being assigned family roles, economic designations, or simply the inability to be an independent individual free to make their own decisions, women living in this patriarchal structure were truly socially and legally inferior to men.

Despite participating in the American Revolution just like men, women continued their traditional "duty" and were expected to seek marriage and reproduce for the family instead of working, running businesses, or having a career in general like men. However, early visionary like Abigail Adams in 1776 had a different view. "Do not put such unlimited power into the hands of the Husbands. Remember all Men would be tyrants if they could. If particular care and attention is not paid to the Ladies we are determined to foment a Rebellion, and will not hold ourselves bound by any laws in which we have no voice, or Representation."[11] The letter, written a few months before the debut of the Declaration of Independence, explicitly showed early feminists' self-awareness of women's predicament and their passion for rights movements. Nevertheless, at Adams' time, women were unfortunately "forgotten" in the Declaration of Independence. The later Constitution and the Bill of Rights made little progress for women rights as well. Under the principles of coverture, women were still under the protection and authority of their male counterparts and were not considered as part of the public citizenry. Lacking any major advancements for women's rights after the American Revolution and the first few amendments of the constitution, the different aspects of women rights will still take decades to be established.

Around the 18th and 19th centuries, the three fundamental features of the common law included coverture, lifetime commitment, and sexual monopoly[12]. Often expressed as marital "unity", coverture was the governing legal regime of the period. When the wife's legal identity was covered by her husband, she did not have the right to own property, enter contracts, control income, and was subjected to 
reasonable discipline by the husband[13]. The popularity of such concepts can be traced in multiple aspects of the American society. With religions carried on and developed from the origins in Europe, the values embedded in common law were consistent with the religious beliefs in the United States. On top of that, the common law was to a certain extent affected by the agricultural society. Before the industrial revolution, the majority of society was agrarian. Consequently, largesize households with more offspring were prevalent. Furthermore, the common law was against procreative conduct outside of marriage and non-procreative conduct inside and outside of marriage. Fornication, adultery, and other conduct were criminalized by early states in the United States. This regime set the tone for marriage to be the compulsory prerequisite for procreative activities and procreative activities to be one of the main goals of marriage creating a kind of sexual monopoly[12]. Lastly, understanding marriage as lifelong commitments, divorce was not favored around the period. Most American judges rejected any divorce even if the husband cheated, abused, or assaulted the wife. The only way divorce was allowed was when one party committed a public crime. Overall, women were simply accepting their new identity and rights when going into marriages while obeying their obligations to bear children. In simple terms, instead of working and pursuing a career, women were entitled to create conditions favorable for their husband to do these.

Despite these deeply planted traditions, 19th-century feminists marked the start of a series of movements and events leading to the establishment of marriage rights for women. They believed that coverture essentially put women in the position of servants or even slaves in a marriage, while the inability to divorce caused women to be trapped in detrimental situations. Elizabeth Cady Stanton was one of the leading feminists. She lobbied in the New York legislature for reform and led the social movement pressing for changes and liberalizations. Around the 1850s, the supporters for altering marriage and divorce situations with such movement increased dramatically. The rise of the middle class and the economic development of the nation led to a drop in fertility rates. Women were gaining more rights and receiving quality education at the same time. Another factor is that while women may not have the right to vote yet, they were essential to the development of the nation in that they were to take care and educate the prospective legislators and eligible voters. Therefore, despite not being able to participate in politics directly, education was still crucial for women. As awareness for their rights increased among women and as middle/upper class men started to consider the marital roles of women from a father's perspective instead of a husband, the demand for marriage rights is inevitable.

Seeing a patriarchal structure as inconsistent with the fundamental ideology of equality in the Constitution of the United States, Stanton and others with similar beliefs also were advocates for the abolitionist movement and the temperance movement. Although not capable of making significant political change themselves, they persuaded their male legislator allies in the other social movements. Following the ideology that stresses the importance of family, states like Arkansas started protecting the family unit against irresponsible husbands as early as 1835 . However, these statutes were mainly protecting the wife's property from the debt of the husband before the marriage. Through a series of efforts, women eventually gained the right to own patents around the 1840s. As more petitions and ideas were submitted, it caused a stream of heated debate and discussion in society. Eventually, by utilizing the power of anti-slavery legislators, the Married Women's Property act of 1848 was passed allowing the wife's property to remain a separate entity after marriage[14]. Although not immediately revolutionary, this did lead to rapid changes in several states mainly in the north where the small middle class, urbanized families resided.

Within a few months, Stanton and fellow feminists assembled at the Seneca Falls. They wrote the Declaration of Rights and Sentiments advocating for women to fight for their rights guaranteed by the constitution instead of accepting that the constitution only applies to men. The declaration opposed coverture, marriage for life. In 1853, they reassembled to once again advocate for the other rights like controlling earnings, entering contracts not promised by the previous statues[13]. As the abolitionist movement operated in full progression on the side, they received significant support from their ally abolitionists while participating directly in the movement as well. Nonetheless, this was faced with unprecedented opposing forces. Different from previous statues that were wanted by male counterparts, this was solely out of the interest of the wives. Some deemed it against their religion and may directly lead to social instability as women move away from the domestic sphere. Despite the opposition, the 1860 Married Women's Property Act was passed after work in the legislature and organized conventions in fifty-four states created by Stanton's friend, Susan B. Anthony. This granted women the right to participate in economic activities, retain earnings, convey property, enter contracts, sue in their own name to ensure economic rights, and as a joint guardian of their children. Other states soon followed this model and created other statues[12].

The progress in this period marked the critical shift in women's marriage rights. However, gaining success legally was far from the full establishment of marriage rights. Socially, time is needed for society to accept the new measures and the full application of the measures requires further efforts especially in the judiciary branch. Courts usually still follow the common law and try to not disturb the original structure as much as possible. 
Moreover, on the divorce front, maintaining the philosophy from married women property statues, Stanton and fellow feminists believed that marriage itself should be treated as a contract[12]. After the struggles of the 19th century, women started to be viewed as independent individuals who are capable of making decisions for themselves. Gaining more autonomy throughout the decades, they were active participants of social, economic, and political activities in the 20th century. Fertility rates continued to drop, but surprisingly, divorce rates increased significantly. As mentioned, divorce was only allowed when one party committed a crime. However, some escaped the law by obtaining divorces in states with liberal laws such as Nevada which granted divorce without any fault in 1931. The constitution requiring the recognition of such laws allowed couples to simply go on trips to other states for divorce. On the other hand, couples without the economic power can choose to abuse local alternatives where one party confesses to a lightly prosecuted crime to seek divorce. Eventually, between 1967 and 1985, all states allowed no-fault divorce to take place. California became the first state to allow no-fault divorce through their Family Law Act of 1969. At the same time, thirty-four of the fifty states allowed unilateral divorce where one party is allowed to force divorces without consent or overriding the objections of the other party[14].

Stepping back to the period when Stanton and fellow feminists assembled at Seneca falls, their aspirations were not solely limited to the marriage and economic freedoms of women. Large portions of effort were also devoted to establishing the critical aspect of women suffrage. The 1853 Rochester convention reinforced the idea of women suffrage. Nonetheless, the issue was that suffrage could not be reasonably connected as a necessity to protect the family against irresponsible husbands. Therefore, the male legislators would not be convinced to support women suffrage. Despite these difficulties, the movement continued to involve suffrage extensively. When Anthony and colleagues travelled the states to provide lectures about women's equal rights and organized conventions, women suffrage was also a prevalent issue discussed in the lectures. The newspapers at the time were filled with heated debates over the wife's property rights and women suffrage. Furthermore, the campaign of Stanton and fellow feminists leading to the 1860 Married Women's Property Act also inspired feminist leaders in other states to lobby for these rights along with women suffrage. This laid the blueprint for the continuous feminist social movement[15].

Additionally, the establishment of property rights gave feminists a strong argument for their cause. They argued that women lacked the tools to protect their property by law. Without the right to vote, to hold office, or participate in the legislature, women will simply be taxed with control solely in the men's hands. This is similar to the old saying of "Taxation without representation" which was one of the fundamental issues leading to the American revolution. Many could emphasize with this argument the feminists made and saw the direct violation of their philosophies for an ideal government.

Unfortunately, despite the close relationship of the advocates in the abolitionist, temperance, and feminist movement, the aspirations of the feminists were not settled by their male counterparts when the opportunity arose. The Fifteenth Amendment of 1870, the last of the reconstruction amendments, granted suffrage to African American men yet their fellow abolitionists rejected the suggestion to include sex along with "race, color, or previous condition of servitude." With the continuation of the feminist movement, women persisted with their efforts and continued to gain political and economic influence or opportunities over the decades. Although African American women continued to work in fields like domestic servants or agriculture while immigrant women filled the low paying market, white women had countless options outside of households including office work like telephone operators. Political organizations that followed the first wave of suffragists at Seneca Falls like the National American Woman Suffrage Association and the National Women's Party played important roles as well. On top of that, part of the motivation for women suffrage also came directly from the temperance movement. Temperance activists realized that their agendas would be better achieved if women could vote as the concern for irresponsible, drunken, abusive husbands can be dated back to the start of the feminist movement. Finally, World War I also did contribute to the advancement of social reform. Although some believe it will hinder the reform, the war ultimately benefited the movement as women's wartime contributions earned more power for women. Nonetheless, it will not be until 1920 that the ratification of the Nineteenth Amendment guarantees women's suffrage. Just as the Married Women's Property Act provided the necessary prerequisites for women suffrage, women suffrage, which allowed the voices of women to be heard politically, laid the foundation for any further development of women rights like the birth control movement.

On the reproduction side, dating back to the independence of the United States, the common law adopted from Europe did permit abortion before quickening, or in other words, feeling fetal movement. This was usually between sixteen to twenty-five weeks into pregnancy. Abortion procedures were commonly performed and even advertised if due to a lack of resources to raise a child[16].

Moving to the period when economic rights in marriages and marital rights were sought after by Elizabeth Cady Stanton and fellow feminists, broader aspects like the power to control one's own body was a 
crucial concern as well. Whereas the debate nowadays mainly centers around abortion itself, issues involved with reproductive rights were abundant at the time. In fact, society trends had even pushed new statutes to reaffirm the philosophy that women's ultimate goal is to bear and raise children after marriage to a man. Although Stanton and fellow feminists may be considered quite successful in terms of securing marriage and related economic freedoms, advancements in reproductive rights were less successful. While women started to gain economic rights in the mid to late 1800 s, states were passing statues against the concept of abortion at the same time. The sale and use of contraceptives were also the targets of some of the statutes as there were originally no limitations to that in the common law. The reason for making abortion illegal varied between the states, some factors may include religious conflicts, fear of immigrant children becoming the majority of the population. The Comstock Act of 1873 was one of the significant statutes that defined contraceptives as obscene, illicit and banned the dissemination of any information or products related to birth control[17]. These statutes led by the traditional contempt, condemnation against any kind of nonprocreative sex and extramarital sex once again enforces the traditional values around sex, which, in turn, weakens the control of women over their own bodies.

In this period of rapid advancement of women's economic rights and the development of the economy accompanied by urbanization, opposition to these regimes was persistent. Women who wanted to enjoy the economic opportunities to work wanted ways to limit pregnancies, not to mention the extensive amount of resources children will consume. Especially after the implementation of women suffrage at the end of World War I, society had shifted to favor the idea of sex for pleasure. Therefore, the criminalization of abortion and contraceptives were not effective and sufficient. Women utilized back alley abortion from illegal practitioners that were dangerous and often deadly[18]. As the demand for contraceptives increased and the lack of resources devoted to prosecute the products, there were nearly no consequences to the violation of these laws in the large market of contraceptives.

Despite lacking effects in its application, the Comstock Act and other statutes created a social stigma around contraceptives and birth control which prevented the education of these essential knowledge to the lower class and middle class women. Nonetheless, opposition to the act was intense. Margaret Sanger, an outspoken birth control activist, opened the first public birth control clinic in New York in 1916. She was consequently arrested, convicted, and sent to jail. Appealing the decision to the supreme court, Sanger argued utilizing the previous economic right gains and claimed it a deprivation of life and liberty as pregnancy often endangered the wellbeing of the mother. Unfortunately, the supreme court rejected the arguments. However, with the medical evidence provided, statutes gradually shifted to provide some flexibility for physicians to prescribe contraceptives due to health concerns. Sanger continued to advocate for such measures and founded the American Birth Control League in 1921[17]. Despite the opposition from certain authorities, public support of this birth controlled movement fuelled by the ideology change of less emphasis on procreation in marriage and sex. An important aspect to consider is that contraceptives and abortion issues applied to every single woman no matter race or social class. This had the effect that none other social movements can have: it brought all women of different origins together on the same boat. By the end of the 1930s, public birth control clinics were a common sight in states. Starting around the same time, state-supported programs were put in place and eventually federal funds as well. In the Griswold v. Connecticut case of 1965 , the supreme court ruled that sexual intimacy shall be enjoyed without necessary family expansion against the strictest anti-contraception law[12]. This marked the change in the idea that sex within marriage was solely for the reason of procreation. Contributing to the control of timing and number of children, women not just gained access to the knowledge and devices but autonomy in marriages to an extent regarding their body.

Continuing the trend, these advancements in rights around contraceptives were then followed by changes to abortion under the continued influence of the birth control movement. In 1967, Colorado became the first state to decriminalized abortion and liberalized its abortion law. Multiple other states followed with their own statutes. However, these allowed abortions are all under extreme circumstances such as rape, incest, or significant health concerns of the mother[18]. It was not until the landmark case of Roe v. Wade in 1973 that the supreme court made safe, legal abortion from professionals possible for women. Texas statutes at the time prohibited any legal abortion other than under the circumstances of saving the mother's life. Jane Roe (Norma McCorvey), who wanted to terminate an unwanted pregnancy was denied a legal abortion. Along with attorneys that wanted to challenge anti-abortion laws, she filed a case against Henry Wade, the district attorney of Dallas that defended the Texas abortion laws. The Supreme Court heard the case and ruled the Texas statutes that were against abortion other than lifethreatening circumstances unconstitutional[19]. The Court decided that abortion rights fell under the right to privacy guaranteed by the Due Process Clause of the Fourteenth amendment. This officially established that the Constitution protects the abortion rights of women with limited government interference despite the consequent social turbulence regarding the ruling of the case[20]. 


\section{ANALYSIS AND DISCUSSION}

The Chinese legal system compared to that of the United States had been stereotyped to be superannuated and inhumane. However, the legitimacy of this notion can be much debated, especially around the ground of women's rights. The conventional wisdom is that the United States has long enjoyed a modern legal system, recognizing rights for everyone while China's legal system has been relatively old-fashioned and has not ensured rights for women and other minorities. As this paper has demonstrated, this conventional wisdom is greatly oversimplified. Dissecting the issue from the marital, reproductive, and political aspects of women's right, American women have not always enjoyed more equality and freedoms than women in imperial and twentieth century China.

Chinese and American women were of similar status in marriage during the late 1800s and the first decade of the 20th century: coverture was established in both societies. Specifically, women were viewed as one of subordinate will in China. However, prerequisites set by convention for divorce altered and no-fault divorce was legalized in the 1930s as the country advances into the republic era. Compared to the United States, where nofault divorce did not become widespread until the 1960s, China was more flexible on the matter of the dissolution of marriage. The attitude on abortion, too, varied dramatically. Not until the decision of the landmark case Roe vs Wade did abortion per se became nationally accepted by courts in the United States. Although abortion was shortly criminalized from 1911 to 1930 in China, the society had always been open to abortion in protection of the mother and later as a means of population control. In 1950, China was also approximately a decade earlier to embrace the use of contraception whereas contraceptives went through a series of social debates in the United States. The 1950 Marriage Law passed by the Supreme Court of the People's Republic of China abrogated sexist conventions and established gender equality in different aspects of daily life whereas certain states refused to ratify the Equal Rights Amendment passed in 1972. Nonetheless, equality is beyond the scope of issues of this simplicity. It had yet to be fully achieved simply with the ratification and implementation of the ideal. Women's suffrage was implemented two decades earlier in the United States than in China as well. However, the idea of women's political participation was proposed by Chinese elites as early as the 1890 s.

Historically, mainstream ideology plays an important role in shaping the legislative evolution of a country. In China, Confucianism as a doctrine had been widely recognized by the Han Dynasty (202 BC-220 AD). Upheld as a state ideology, Confucianism has influenced innumerable aspects of the Chinese society, including the Chinese judicial system, which stressed the importance of fixed social roles and a hierarchical society. As for the notion of equality prevalent in modern Western societies, it was not a primary concern for pre-revolution Chinese legislators. The United States legal culture, on the other hand, tends to be under Christian influences that accentuated equality before God, and God's absolute authority over its subjects. After the French Revolution, humanitarianism and republicanism that both highlighted the importance of human rights and liberty became prevalent. These ideological trends in Eastern and Western civilizations partially explain the reasons behind their drastically different attitude toward, for instance, abortion (Confucianist parental authority and Christian God's authority) and the use of contraceptives. Precisely because of the emphasis on social hierarchy and women's subordinate social status underscored in Confucianism, it seems plausible to the general public to believe that the Chinese legal system does not protect the rights of certain social groups, for example, women.

As the previous section of the paper demonstrates, the history regarding the evolution of women rights in China and the United States came a long way. However, the disparity that influenced the development processes ultimately caused the discrepancies to still holds true today.

Basing off religion, the different conceptual foundations for the two countries' political systems obviously do not come as a surprise. Whereas the United States elites had advocated the concept of federalism since the beginning of the nation, Chinese regimes tend to always construct a centralized government even in the republic era. This potentially is the greatest factor that contributes to the contrasting general trajectories of the evolution of the two legislation: the bottom-up approach versus the top-down approach.

The United States starting with the failure of the Articles of Confederation came to realize their ideal form of government to be this federalist government, which combined a central government with regional governments. Indeed, the main principles behind these ideas were perhaps the separation of power just as seen in the three-branch set up of the government. Of course, the separation of power weakens the overall control of the central government. Consequently, power becomes distributed to a variety of positions within structural governments and society. As seen in the United States' significant adjustments in legislative history, majority of the changes are initiated by widespread social custom/value revolution, or social movements of the public. These are characterized by this concept of a bottom-up approach towards the ultimate result of legislative changes where internal social forces, including mostly grassroots movement, played a major role. Although the idea behind the notion of feminism may not be newly invented at the time, the feminists that first gathered at Seneca Falls symbolized the beginning 
of the first wave of feminism in the United States. Notable leaders, including the previously mentioned Elizabeth Cady Stanton around the New York areas, were yet to become well-known, influential reformers at the national level. Starting from lobbying in the New York legislature, she would later initiate changes around the nation along with her friend Susan B. Anthony. Additionally, in the early 20th century, as the fertility rates continued to drop, women gained more economic opportunities outside of the home as well. The expansion of the economy along with technological development potentially made the revolution inevitable. Resulting from these quickly altering social trends is the legislative changes that attempted to accommodate them. Nonetheless, this is not to say that the United States was completely free from centralized efforts of the federal government or external forces like global wars. These may have played an even larger role to some extent.

On the other hand, the legislative history of China displays a similar yet vastly different evolution. The Chinese law with an emphasis on social hierarchy was accompanied by the largely Confucianism ideology of fixed social roles that mainly disregarded the so-called "equality" among the people. On the contrary, modern western laws may have placed more emphasis on Christian values of equality before god, humanitarianism that favored human rights and individual liberty. With a long history of imperial dynasties before the period of the late nineteenth century, China, moving to the republic era, witnessed reforms and revolutions at a fundamental scale in its institution and culture (These may or may not have overshadowed the women's rights advancements and undermined the efforts put in by feminists compared to their counterparts in the United States.) Indeed, these large scale, nationwide political and economic changes are the pushing factors that facilitated the reforms of late nineteenth- and early twentieth-century China. As a result, the other minor adjustments like women rights that were naturally led by the shifting ideologies can be attributed to the major changes. Whereas the United States takes a bottom-up approach, it appears that the legislative changes in China take place more in a topdown approach. The state-led actions dominated the internal field while external factors forced down upon the country facilitated the other changes. For example, the Republic Civil Code established after the abolition of feudalism modeled after the ones originated in Switzerland and Germany. These western influences or responses to western modernization automatically favored the western equality and brought some room to certain women rights aspects. Other factors like the rapid development of the Port of Shanghai further contributed to globalization and introduced western ideologies to China. Furthermore, in an effort to eliminate foreigners' extraterritorial legal privileges, which were considered as infringement to China's judicial sovereignty, domestic reformers were sometimes forced upon the idea of copying western legislation as foreigners claimed the local laws as cruel and "barbaric". Another relatively recent example is the population control policy implemented by the Chinese government at the end of the 20th century known as the One-Child Policy. Despite being potentially one of the most successful, effective population planning schemes, its moral implications and influence on women's rights are largely debatable. Overall, these external forces and centralized efforts caused the legislative changes, but that is not to say social trends and movements, action at the grassroots level had no effect over the work led by the centralized government. In fact, the second wave of feminist movement, which had its advocates developing from only the elite class to gradually average individuals, made critical achievements. In the early 1920s before the formation of the national government under the GMD, the main four provinces directly reacted to the second wave of activism and passed constitutions that guaranteed gender equality in terms of women suffrage.

Analyzing the situation in the two countries, it is clear that legislation and social conditions are mutually shaping each other. Laws are proposed to accommodate the new social trends and may have molded them. However, to what extent does society influence law and vice versa? As one of the products of society, laws are written and established by members of the society for all to follow yet these rules and regulations are consistently questioned as society advances. Following this intriguing cycle, this sure will continue to be one of the significant underlying questions as the future of legislation in these two countries unfolds.

\section{CONCLUSION}

Overall, the bottom-up social movement approach of the United States to a certain extent reflects the democracy, federalism, freedom of speech/association, and Christianity that is highly valued in western society. On the other hand, China's top-down approach reflects the difference between a centralized government and democracy, with some degree of influence from its Confucian heritage. Yet what are the implications of these approaches in today's society? Perhaps the rights, freedoms, and status of women in the United States and China are more similar than they were 200 years ago. Despite the difference in the system and the paths taken, women's role is becoming increasingly unanimous. The world is more interdependent than ever before through the rapid globalization of our society. Thus, the question becomes where would this trend in modern society for freedoms and equality take women's rights to?

It is important to note that the thorough discussion of the legislative history along with the comparison and analysis is not in any form aimed to address which one is the better or more effective. In a world of contrasting legislation, issues regarding rights are prevalent around 
the world. It is mostly assumed in western cultures that the rights of individuals must be placed at a certain height to prove or ensure the protection of individuals, minorities. Nonetheless, it is not often considered that certain countries lack the specifics around the notion of rights. With different political and social conditions, it is still too complicated to define or determine how much autonomy people possess in countries. Legislation develops differently under a variety of circumstances involving religious backgrounds, social ideologies. Perhaps sometimes democratic societies can have downsides in terms of rights while socialist societies may even be more considerate or advanced in terms of rights and autonomy of the people. Through this historical process, legislation advance in their own ways following unique trajectories with respect to their country. However, when considering the development of legislation, advancement is perhaps not a great word. Indeed, the development of legislation is never a one-way journey. Despite the constantly changing trait, legislation may not be always moving forward. For instance, the Heartbeat Bill, a legislation restricting abortion, has been controversial in recent years. The legislation illegalizes abortion when fetal heartbeats can be detected. Depending on the perspective, this new act can be seen as a step backward.

In the current society, the mainstream view following mass media opinions often portrays stereotypical views when evaluating the advancement of liberty and corresponding legislation. Comparing the United States legislation that focuses on humanitarianism and the Chinese legislation consisting of a sense of Confucianism, it is essential to realize that no one standard or criteria can account for the judgment around whether the legislation is refined and developed or whether groups and individuals are treated equally. These developments may be progressive but sometimes conservative. On top of that, family privileges, individual autonomy, and equality for all is never the only concern for legislation. A simple example is the significance of social stability and the ability to contain a group of people under a form of government without anarchy.

Finally, one must be cautious about cultural biases when examining the legislative history and legal conventions different from one's own. Using a comparative lens, this paper seeks to avoid culturalism and essentialism in the analysis of the two legal systems. The generalized impressions of a country, a culture, a people, or a political entity are not sufficient to explain the progress of legislation and the development of the legal and social status of a certain social group. The evolution of legislation is shaped by a multitude of factors, included but not limited to, political revolution, economic development, globalization, nationalism. These internal and external forces may be viewed differently by contrasting perspectives. Thus, understanding the development of legislation following unique historical trajectories is necessary to obtain a rational view of a country's legislative system.

\section{REFERENCES}

[1] Huang, Philip C. C. "Women's Choices under the Law: Marriage, Divorce, and Illicit Sex in the Qing and the Republic." Modern China 27, no. 1 (January 2001): 3-58. http://www.jstor.com/stable/3181363

[2] Kuo, Margaret. "Spousal Abuse: Divorce Litigation and the Emergence of Rights Consciousness in Republican China.” Modern China 38, no. 5 (2012): $523-58$. https://doi.org/10.1177/0097700412456170

[3] Xue, Y. S., Dulicunyi (digital text). Accessed August 31, 2020. http://www.terada.law.kyotou.ac.jp/dlcy/index.htm

[4] Ransmeier, Johanna S. Sold People: Traffickers and Family Life in North China. Cambridge, Massachusetts: Harvard University Press, 2017.

[5] Sommer, Matthew Harvey. Polyandry and Wifeselling in Qing Dynasty China: Survival Strategies and Judicial Interventions. Oakland, California: University of California Press, 2015.

[6] "Enforcement Law for Part IV, Family Law of the Civil Code of the Republic of China (1930)." Laws $\&$ Regulations Database of the Republic of China. https://law.moj.gov.tw/LawClass/LawParaDeatil.a spx?pcode $=$ B0000001\&bp $=103$

[7] Edwards, Louise. "Women's Suffrage in China: Challenging Scholarly Conventions." Pacific Historical Review 69, no. 4 (2000): 617-38. https://doi.org/10.2307/3641227

[8] Gao, H. S., Criminal Law of Qing Dynasty. Institute of Law, Chinese Academy of Social Sciences. Accessed August 15, 2020. http://iolaw.cssn.cn/bwsf/201104/t20110415_4611 883.shtml

[9] "Criminal Code of the Republic of China (1935)." Laws \& Regulations Database of the Republic of China.

https://law.moj.gov.tw/LawClass/LawAll.aspx?pco $\mathrm{de}=\mathrm{C} 0000001$

[10] "Marriage Law of the People's Republic of China (1950)." The Web site of the National People's Congress (NPC) of the People's Republic of China. http://www.npc.gov.cn/wxzl/wxzl/200105/30/content_136774.htm

[11] Eskridge, William N., Jr. "Women's Rights Under the U.S. Constitution." Reading, July 28, 2020. 
[12] Eskridge, William N., Jr., and John A. Ferejohn. A Republic of Statutes: The New American Constitution. New Haven, Connecticut: Yale University Press, 2010.

[13] McClain, Linda C., and Joanna L. Grossman. Gender Equality: Dimensions of Women's Equal Citizenship. Cambridge: Cambridge University Press, 2012.

[14] Wright, Gerald C., and Dorothy M. Stetson. "The Impact of No-Fault Divorce Law Reform on Divorce in American States." Journal of Marriage and the Family 40, no. 3 (1978): 575. https://doi.org/10.2307/350938

[15] Schuessler, Jennifer. "The Complex History of the Women's Suffrage Movement." The New York Times. The New York Times, August 15, 2019. https://www.nytimes.com/2019/08/15/arts/design/ womens-suffrage-movement.html

[16] "Limiting Births in the Early Republic." Digital History. Accessed August 15, 2020. https://www.digitalhistory.uh.edu/topic_display.cf m?tcid $=134$

[17] McBride, Dorothy E., and Jennifer L. Keys. Abortion in the United States: A Reference Handbook, 2nd Edition. ABC-CLIO, LLC, 2018.

[18] "History of Abortion." National Abortion Federation, January 29, 2015.

https://prochoice.org/education-andadvocacy/about-abortion/history-of-abortion/

[19] Skelton, Chris, and David S. Kemp. "Roe v. Wade, 410 U.S. 113 (1973).” Justia Law. Accessed August 15, 2020.

https://supreme.justia.com/cases/federal/us/410/11 3/

[20] Greenhouse, Linda, and Reva B. Siegel. "Before (and After) Roe v. Wade: New Questions About Backlash." The Yale Law Journal 120, no. 8 (June 2011): 2028-87.

http://www.jstor.com/stable/41149586 